\title{
Changes, Losses, and Challenges on Transformation of the Urban Place: A Narrative on Istiklal Street, Istanbul from the 1900s Until Today
}

\author{
Mudanças, Perdas e Desafios na Transformação do Lugar \\ Urbano: Uma Narrativa na Rua Istiklal, Istambul, de 1900 até \\ hoje
}

Asiye Nisa Kartal [a] (iD)

[a] University of Nottingham, Nottingham, Nottinghamshire, United Kingdom

How to cite: Kartal, A. N. (2021). Changes, losses and challenges on transformation of the urban place: a narrative on Istiklal Street, Istanbul from the 1900s until today. urbe. Revista Brasileira de Gestão Urbana, v.13, e20190335. https://doi.org/10.1590/2175-3369.013.e20190335

\begin{abstract}
Over the years, the socio-cultural structures, architectural compositions of Istanbul have changed gradually. Unavoidably, Istanbul's urban places have been affected as they have gained new faces through the wrongdriven, top-down, controversial changing processes. Especially since the 1990s, the changes have gained momentum, many controversial modifications have occurred in the heart of Istanbul. Istiklal Street has turned into a symbol of the transformation that Istanbul has been going through. The process brought about the rapid disintegration of the Street's unique, hybrid constitutions and distinctive qualifications. Nearly all the characteristic landmarks that made Istiklal Street special have disappeared one by one and the area is converting into a place that has lost its spirit. To understand how the Street has shaped historically and what has lied at the behind stages, the study begins with a qualitative discussion on the formation of the area since the 1900s. But the focus of the narrative is based on the period from 1990 until today with an explanatory approach to criticise by which mechanisms and actions the area transformed and come today. The study stresses that the potentials of the urban probabilities, socio-spatial compositions, tangible and intangible features are responsible for the future of this place.
\end{abstract}

Keywords: Istiklal Street. Urban Place. Transformation actors and mechanisms.

\section{Resumo}

Ao longo dos anos, as estruturas socioculturais e as composições arquitetônicas de Istambul mudaram gradualmente. Inevitavelmente, os lugares urbanos de Istambul foram afetados à medida que ganharam novas faces por meio dos processos de mudança controversos, conduzidos de forma errada e de cima para baixo. Especialmente desde os anos 1990, as mudanças ganharam força, muitas modificações controversas ocorreram no coração de Istambul. A rua Istiklal se tornou um símbolo da transformação pela qual Istambul está passando. O processo trouxe a rápida 
desintegração das constituições híbridas e exclusivas de Street e das qualificações distintas. Quase todos os marcos característicos que tornaram a Rua Istiklal especial desapareceram um a um, e a área se transformou em um lugar que perdeu seu espírito. Para entender como a rua se configurou historicamente e o que ficou nos bastidores, o estudo parte de uma discussão qualitativa sobre a formação do bairro desde os anos 1900. Mas o foco da narrativa se baseia no período de 1990 até os dias atuais com uma abordagem explicativa para criticar por quais mecanismos e ações a área se transformou e vem hoje. O estudo destaca que os potenciais das probabilidades urbanas, composições socioespaciais, feições tangíveis e intangíveis são responsáveis pelo futuro deste local.

Palavras-chave: Rua Istiklal. Lugar urbano. Atores e mecanismos de transformação.

\section{Introduction}

For structuring the narrative of this article, a qualitative explanatory based research analysis has been followed. Mainly, for the 'urban history' and 'intangible cultural heritage' literature of Istanbul, and the Beyoglu neighbourhood, most of the latest documents have been searched in English and Turkish languages. For dipping into the matters of the 'spatial, socio-cultural and economic modifications', and 'planning, designing and transformation procedures' of Istiklal Street; multiple sources such as published documents (books, journal articles, thesis, conference proceedings, newspaper' articles) have been analysed. Secondly, the urban plans, reports, and administrative documents of the Beyoglu municipality give us an idea about the latest transformation stages of the area used as the additional sources of the narrative. With the aim to clearly understand the mechanisms and actors that have lied behind the transformation process of the area, some papers on the law and regulation strategies and policies of the area have been examined. Moreover, the discussions which have been put forward by expert and non-expert people on the internet and social media channels have been reviewed. All these sources have been analysed to extract the information about 'how the area has transformed spatially and socio-culturally' and 'what has been changed and is still changing, and what has been lost in the area'. It was expected to picture the story of the area in a comprehensive way.

Istanbul of Turkey is a sophisticated urban fragment with an urban population of over 15 million today. It is settled down more than sixty kilometres along the Marmara shores and has a Eurasian character due to its position on two continents; the western side of Istanbul is in Europe, as the eastern side is in Asia. The qualifications that make Istanbul specific among the world cities are its distinctive past and historical, cultural, architectural diversities and core stations of international transmissions. Through the years, different variables have impressed the changes in Istanbul's urban configurations; the multiple factors have been interrelated, such as internal socio-economic and political movements, as well as the shifts originating from external global elements. From government-driven, top-down, gigantic projects, Istanbul has embodied the issues of neoliberal urbanisation in the most extreme ways possible, as the undeniable truth, this process has generated highly problematic spatial dynamics within the area. The transformation of the area has constituted a warning sign of being a playground for different factors (Ekmekci, 2012; Ekmekci, 2014). So, the area has been risked for missing its diversity and valuable components that link it to its multicultural past, historic architectural and cultural heritage (Eder \& Öz, 2014). The controversial side of the latest developments have been related to their speeds and the overwhelming role of the governance in the process, unavoidably, the area's transformation has been criticised mainly due to the excessive centralisation of decision-making and the lack of consultation with citizens before projects surfaced. The case of Istiklal Street has been indeed symbolic of the kind of transformation that Istanbul has been going through since the 1990s.

The article discusses that Istiklal Street, which has been one of the important public places of Istanbul due to its historical, and socio-cultural background, has witnessed many breaking points since its inception over a century ago. As the main thoroughfare in the Beyoğlu area, it rose to prominence as the 'Grande Rue de Pera' in the 1850s and became the central artery in Istanbul's heart by the turn of the century. At its 
beginning, it housed European citizens and non-muslim Ottomans such as Greeks, Jews and Armenians. However, when nationalist sentiments have gone through the country after the 1930s, an exodus of the area's minorities has happened. Then, the demographics modified in the 1960s as the migrants from the countryside of Turkey moved into the empty homes in the area. Later 1980s, the students and artists arrived as well; the area tried to revive as the arts and culture events sparked (Cusack, 2018), such as national and international film festivals. After the 1990s, diverse urban transformation projects have been implemented in the Street; the integration with globalisation gained pace, the renovations, alterations have been multiplied, all linked with Istanbul's race towards becoming a global city. All of them has caused changes in terms of the spatial, socio-cultural, economic organisations of Istiklal Street, but the focus of the narrative in this study is based on the process which started in the 1990s that gained momentum after the 2000s.

As this article problematises, due to the upsetting transformation of Istiklal Street after the 1990s, the locals have stopped hanging around, most of the art, culture and entertainment places on the Street have been closed, such as old taverns, bookstores, theatres, and especially movie theatres shut down. Many important figures have left the area amid disruptive construction projects. Greed to earn more has caused empty stores on the Street while the identical faces have been the victims of the process. The spatial patterns have changed in the area, and the socio-spatial and sensorial diversity has started to dissolve due to the urban policies pursued. Istiklal Street's cosmopolitan heritage turned into a trademark for Istanbul's global city projects (Adanali, 2011a; Tekin \& Akgün Gültekin, 2017). Most intellectuals, including artists, columnists, and musicians, agree that the area has lost its soul, its glory, and its magic gradually; the area is far from a rollicking street fair of shoppers, diners, protesters, street musicians, roughly a mile-long sea of humanity, with an iconic tram rumbling down the middle. For years, the problems could not be solved, although the Street has been redone numerous times; and, the Street converted into a street with no fun or liveliness. The changes in the area indispensably injured the distinctive features of the region. Istiklal Street hopes to bring back the good old days after suffering a series of setbacks; meanwhile, it tried to recover from the problematic years (Kömürcüler, 2018).

\section{From the beginning of the 1900s until the Nationalist Movements of the 1930 s and Turkification of the Street}

Istiklal Street, which sits within Pera (Beyoglu) area, burgeoned in the $18^{\text {th }}$ century as a part of Galataan autonomous Genoese and Venetian walled city across the historical peninsula before the conquest of Istanbul (Kayra, 1990). It has been called 'Grand Rue de Pera' (big Street of Pera) by non-Muslims and 'Cadde-i Kebir' (big Street) by Turks (Üstdiken, 1994, p. 266). The $18^{\text {th }}$ century has been the starting point of the unification and association period of the Ottoman economy with the European economy, so the foreign traders have supplied significant benefits (Dökmeci, 1990). As one of the major steps in terms of the 'Westernisation' process of Ottoman Empire, 'Tanzimat Fermanı' (Ottoman Reform Edict of 1856) caused non-Muslim populations to gain more privileges (Batur, 2007), and European style buildings and new social organisations have started to be built in the area (see Figure 1). Then, the construction of foreign embassies and churches created a semi-European, Levantine, and minority rooted Ottoman bourgeoisie who have started living around these embassies (Güney, 2015). Thus, Istiklal Street has evolved quickly into the Ottoman Empire's non-Muslim focus of life and symbolised the most 'western' side of the Empire in terms of architecture, demography, and lifestyle (Adanali, 2011a). 


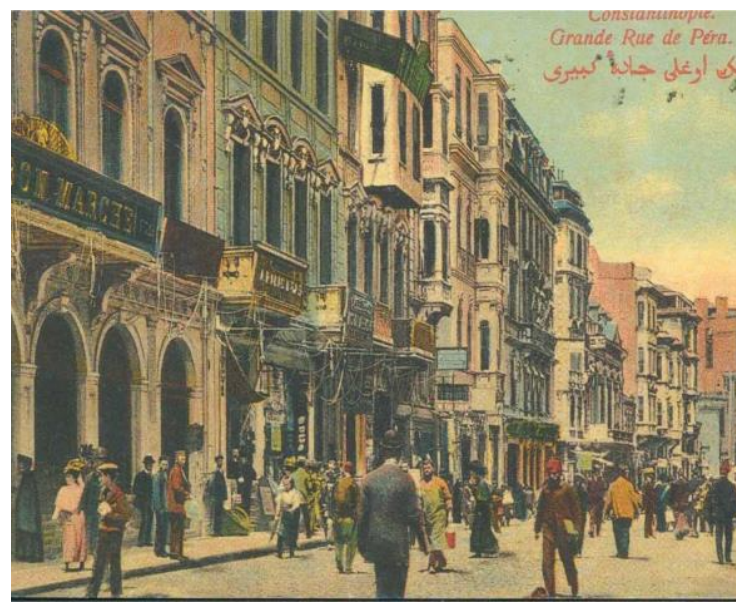

Figure 1 - Istiklal Street in the late 19th century (Placesbrands, 2015).

The district turned into a central area particularly from the second half of the $19^{\text {th }}$ century. The urban innovations have been exclusively intensified in the area (Akin, 2002) to be a sample of the urban planning for the rest of the city. As a result of non-Muslim populations brought their traditions, customs, and cultures (Üstdiken, 1994, p. 266), the theatre, concert, circus, carnival and various feast events have been organised in the district. The dwellers of Istanbul started to meet in the theatres, cafes, clubs, confectionaries, restaurants, bars, and hotels (Akin, 2002, p. 56). Since then, Pera has gained the statue of the 'entertainment centre' within Istanbul with its shops, restaurants, patisseries, cafes, perfumeries, hairdressers, photograph studios, and bookstores; it has also been the 'trade centre' of the city with its trading houses and bureaus as the marks of contemporary urban life (Akin, 1994). The places that opened in the region altered not only the physical environment but also daily life; they offered different socio-cultural organisations comparing with other regions of the city (Güney, 2015). New social relations have occurred, and the European lifestyle became prestigious among Ottoman intellectuals (Batur, 2007); the area has been a focal point where high society met to spend time and wandered by looking at shop windows (Faroqhi, 2008). The spatial designs that emerged in the area through the end of the 19th century affected the inhabitants' social behaviours (Köse, 2011, p. 388-389). The elements of the ethnic dissimilarity and the multilingual and multicultural composition of the area have been quite visible in this era (Tekin \& Akgün Gültekin, 2017).

In the early years of the $20^{\text {th }}$ century, the shopping arcades, theatres, music halls, fashion houses, passages have been built in various styles such as Neo-Classical style, Art Nouveau and Neo-Ottoman style and so on. These buildings have shaped the identical architectural composition, which has been one of the important signs of the area's visual qualities. Istiklal Street's cosmopolite structure has been retained by the end of the first quarter of the $20^{\text {th }}$ century thanks to regulations in favour of non-Muslim Populations, such as the declaration of Constitutionalism II in 1908 (see Figure 2; $1^{\text {st }}$ and $2^{\text {nd }}$ photos). In those years, the area has been a place where many languages have been spoken, and a lot of different ethnical groups have shared urban potentials for living, entertaining and shopping together.

Istanbul lost its position as the capital, and Ankara became the capital of new Turkey after the Turkish Republic's proclamation in 1923 (see Figure 2; $3^{\text {rd }}$ photo), and the embassies in Beyoglu moved to Ankara, and the minorities also left the area. However, Istiklal Street could sustain its cosmopolite attributions in the 1920s (Bartu, 1999). As one of the contributions of cosmopolitism of the area has been made by White Russians who migrated to Istanbul due to the Russian Revolution in 1917, the arrival of Belarusians in the aftermath of the First World War supported the Street to experience its heyday in this period (Adanali, 2011a). However, insufficient planning for the modernisation of Turkey and underestimating Istanbul as the old capital of the previous state Ottoman Empire influenced the cosmopolite attributions of the area to some degree. Istanbul and its some elements based on its cosmopolitanism have been approached as somewhat shabby remnants of an outdated Ottoman past. Consequently, after the 1920s, a modification in 
terms of the spatial and social structure of Beyoglu has happened, such as the widening of the streets, demolishing of old structures, and construction of new buildings (Yada Akpinar, 2010).

The rise of nationalist movements in the world after the 1930s influenced Turkish nationalism movements and the Turkification policy of the Republic; therefore, the decline of the cosmopolite lifestyle for Istiklal Street began (see Figure 2; $4^{\text {th }}$ photo). One of the indicators of this process has been the alterations in the names of elements of the Street with Turkish ones, so the name of the Street (Grand Rue de Pera) has been changed into Istiklal (Independence) (Batur, 2007). Also, the projects of the late 1930s, such as Taksim Gezi Park and Park No II showed the physical infrastructure of the region has begun to be altered (Unlu Yucesoy \& Guvenc, 2010). As a socio-economic factor, the Wealth Tax enacted in 1942 resulted in the bankruptcy of non-Muslims (Tekin \& Akgün Gültekin, 2017). By the end of World War II (see Figure 2; $5^{\text {th }}$ and $6^{\text {th }}$ photos), Istiklal Street started to gradually lose its multi-dimensional entities and complex socio-cultural composition after foreign residents lost their will to remain in Beyoglu.
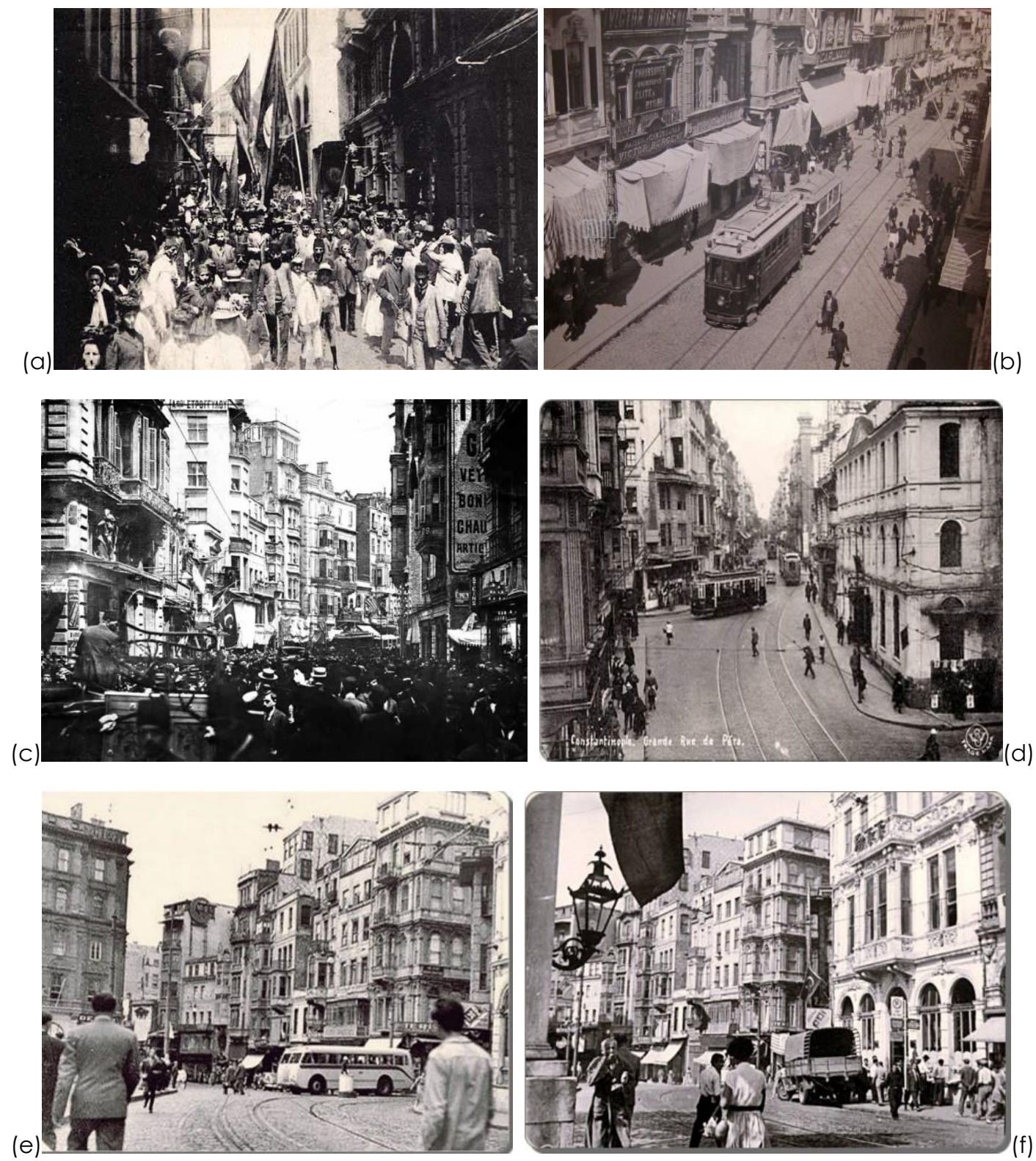

Figure 2 - (a) Istiklal Street after the declaration of Constitutionalism II in 1908 (left above) (Sargut Gelen, 2019); (b) Istiklal Street in the 1910s (right above) (Eskiistanbul, 2019); (c) Istiklal Street after the foundation of the Turkish Republic in 1923 (left middle) (Bellek.beyoglu.bel., 2012); (d) Istiklal Street in the 1930s (right middle) (Aristeia, 2021); (e) Istiklal Street in the 1940s (left below) (Wowturkey, 2015); (f) Istiklal Street in the 1950s (right below) (Pinterest, 2019). 


\section{Istiklal Street turning into an area of decay: The 6-7 September 1955 Case and The Migration, fleeing of merchant and non-Muslim families in 1960s}

One of the major attempts against multicultural lifestyle has been 6-7 September events in 1955 (see Figure 3; $1^{\text {st }}$ photo) because of the attack of provoked people against non-Muslim minorities living around Istiklal Street. The fake news about the bombardment of Mustafa Kemal Ataturk's house (the first president of the Republic of Turkey) in Greece by Greek people has caused a suitable environment for provocation. As a result, a mass exodus of the foreign population has happened, and lots of buildings in the area have been left vacant (Batur, 2007). Therefore, the area's non-Muslim population has reduced quickly after the 6-7 September events (Dokmeci \& Ciraci, 1988). This event caused trauma on Istiklal Street's cosmopolitan composition (Adanali, 2011a), as an accelerated emigration of minorities from Istanbul has actualised. The Government's cancellation of the residence permits of Greek people in Turkey (1964) reflected the Turkification policies that have been applied since the 1930s; nearly 8600 Greeks of Turkish nationality had to abandon Istanbul following 1964 (Cezar, 1991), the ancestor of them lived in Istanbul during the Ottoman period.

With the fleeing of merchant and rich families from Beyoglu after 6-7 September Events, the region began to answer the cheap residence need of Anatolian migrants who immigrated to Istanbul in the 1960s (Dokmeci \& Ciraci, 1988). As the abandoned houses in the area have been occupied by newly arriving immigrants (Adanali, 2011a), Beyoglu's dwellers started to change, and the multi-ethnic and multilingual composition of the region has been destroyed rapidly after the 1960s (Tekin \& Akgün Gültekin, 2017).

In the 1960s (see Figure 3; $2^{\text {nd }}$ photo), the migration to Istanbul from rural areas of Turkey for work facilities changed not only the physical environment but also the social and cultural structure of Istiklal Street and its surroundings. As the industrialisation of Istanbul has improved, the marginalised groups such as sex workers, intersex people, and Roma gipsies and low-income factory workers and their family members began to settle in the area because of the abundance of abandoned buildings. So, around the area, brothels have been opened, drug pushers became visible; therefore, any remaining affluent residents moved to other parts of the city (Üstdiken, 1994, p. 266).
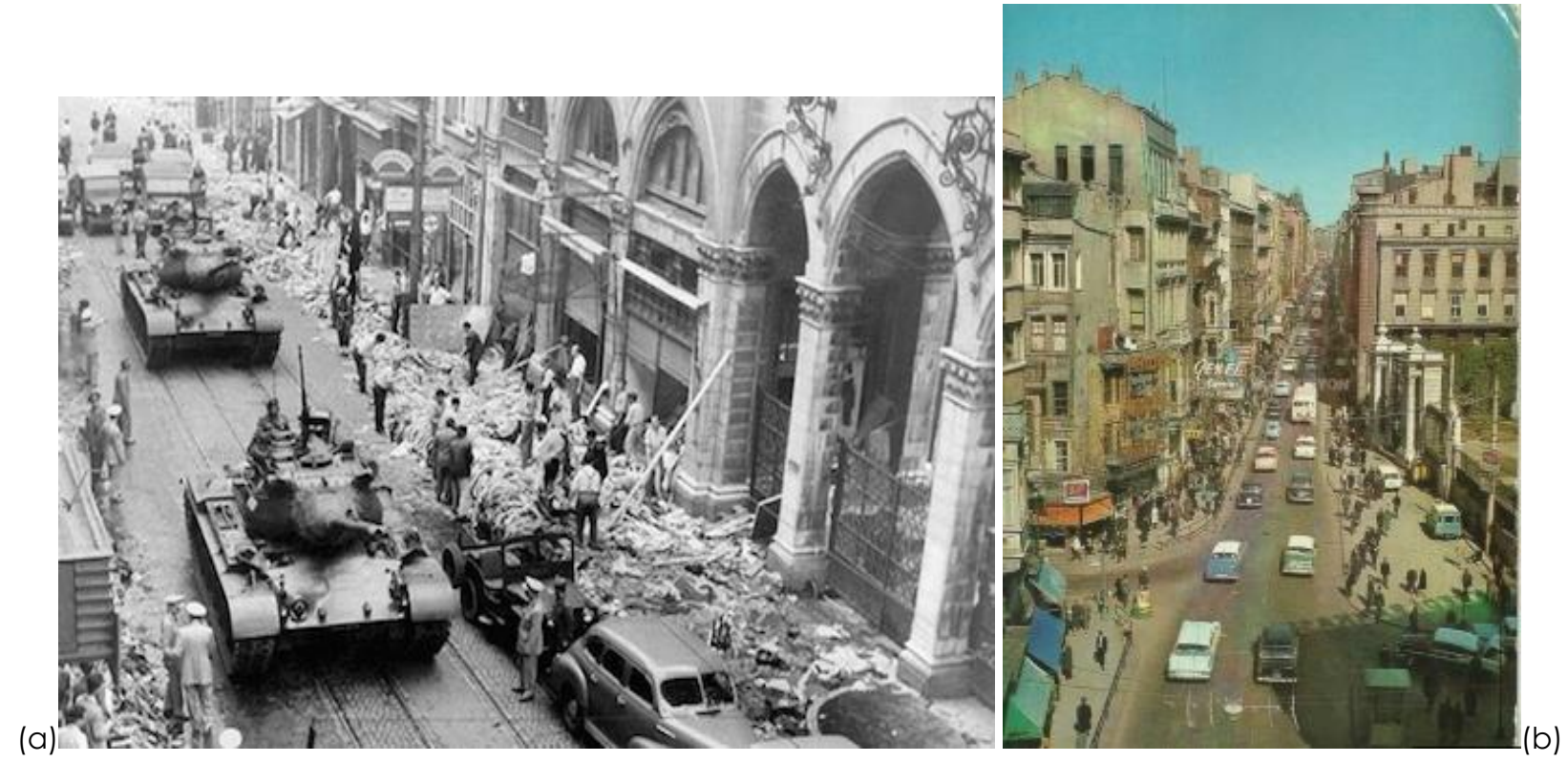

Figure 3 - (a) Istiklal Street after 6-7 September 1955 Events (left) (Haberturk, 2013); (b) Istiklal Street in the 1960s (right) (Steemit, 2020). 


\section{Social, demographic transformation and physical disruption of the area in the 1970s, the First wave of Globalization and Neoliberal Challenges, Demolitions impacts on distinctive texture and Military Coup in 1980s}

After the social, demographic transformation and physical disruption which triggered an increase in the rates of crime and prostitution in this area (Tekin \& Akgün Gültekin, 2017), in the 1970s, Beyoglu has become associated with wretched gangland lifestyles and petty crime on the edges of Istanbul society (see Figure $4 ; 1^{\text {st }}$ photo). What was once the bourgeois and prestigious Pera has turned into a place that would have been unrecognisable except for its architectural style that remained, rearing up with its imposing facades from among the shabbiness (Placesbrands, 2015).

The 1980s was a period that the urban transformation processes based on neoliberal policies began to take place in Turkey (Enlil, 1994; Yalçıntan et al., 2014). In the early 1980s, the January $24^{\text {th }}$ decisions taken by the Turkish Government has been the starting point of economic bonds with international capital (Öktem, 2011). In the period called as 'first neoliberal wave' (Boratav, 2008), the import substitution strategies have been replaced by neoliberal policies based on free-market economy, and it downsized the public sector's role in the economy to provide foreign traders and investors (Öncü \& Weyland, 1997). Istanbul seemed to have the capacity to be a global city with being at the centre of the capital flows that reach both the East and the West, also an economic and political hub for both Turkey and the region. Therefore, the urban places of Istanbul become the most important elements to relate with the global networks that came into the agenda in the early 1980s. For this reason, local authorities put much effort into turning the areas of the city into international trade, finance and culture focus in Europe and the Middle East (Isik, 2010).

In that context, the new urban renewal campaign has been created to advance Istanbul to a 'global city' status, so the city's urban places have been acted as new arenas for the consumers of global lifestyles. There have been built dozens of shopping malls, high-rise office buildings, and mass housing settlements (Keyder, 1999). Simultaneously, luxury hotels and world-class restaurants have been opened one after another to attract tourists; international conferences, film festivals and biennales have been organised as important cultural actions (Güney, 2015). Keyder defines Istanbul's preparations to anchor global networks as a success story since it has been a business platform for the transnational corporate elite as well as a playing field for the cosmopolitan consumers of global lifestyles (Keyder, 2009a, p. 1). However, most urban regeneration and renewal projects have been made with being discussed in unclear conditions through spontaneous decisions (Akpinar, 2014, p. 32). Therefore, the modifications of the city have become highly arguable in the field of academia, social media, and the local communities in the Beyoglu neighbourhood.

In Beyoglu, the transformation experienced in the 1980s has been linked with the actions of the Municipality. The series of urban renewal projects directed by the metropolitan Major Dalan fostered the uncontrolled development of the region (Turan, 2011). Unavoidably Beyoglu has experienced a significant transformation between the years of 1984 and 1989. The projects aimed to attract private entrepreneurs of Istanbul, based on the perspective that Beyoglu has been a place that should be rehabilitated and partially demolished; therefore, the area's architectural texture has been highly penetrated (Tekin \& Akgün Gültekin, 2017). With the aim of converting Istanbul into a 'world-city' and advancing the attractiveness of the areas of Beyoglu, new cafes, restaurants, hotels, cultural buildings, art galleries, bookstores and theatres have been opened in the area (Ozus \& Dokmeci, 2005). In this process, the Association of Beautification and Preservation of Beyoglu was established in 1985 (Güney, 2015) while large-scale demolitions have been carried out for new construction practices (Tekin \& Akgün Gültekin, 2017). In 1988, Tarlabaşı Boulevard (a long street sits near Istiklal Street) has opened after demolitions at Tarlabaşı area (see Figure 4; 4th photo); it generated debates; also, the Chamber of Architects stated the destruction of the old texture meant the loss of distinctive architectural framework of Beyoglu (Bartu, 1999, p. 38), unescapably the opening of the boulevard influenced the patterns of the environment of Istiklal Street (Can, 2012). 
Also, the coup of September 1980 caused a military rule until 1983 (see Figure 4; $3^{\text {rd }}$ photo); Beyoglu has been badly affected, especially, the middle class stayed away from the district, so the district has become a place of danger and ill repute. Hence, the recovery needed a long time (Ash, 1997). Briefly, in the 1980s, considerable changes have occurred in the context of the urban places in Istanbul, important urban renewal projects, and gentrification actions have started (Öncü \& Weyland, 1997). The 1980s has been an interesting period of Istiklal Street (see Figure $4 ; 2^{\text {nd }}$ photo), and its backstreets have been occupied by homeless people, gangsters, and drug addicts, especially in the evenings. Famous brands began to leave Istiklal Street because of the loss of brand values and major falls in sales (Ertep, 2009).

(a)
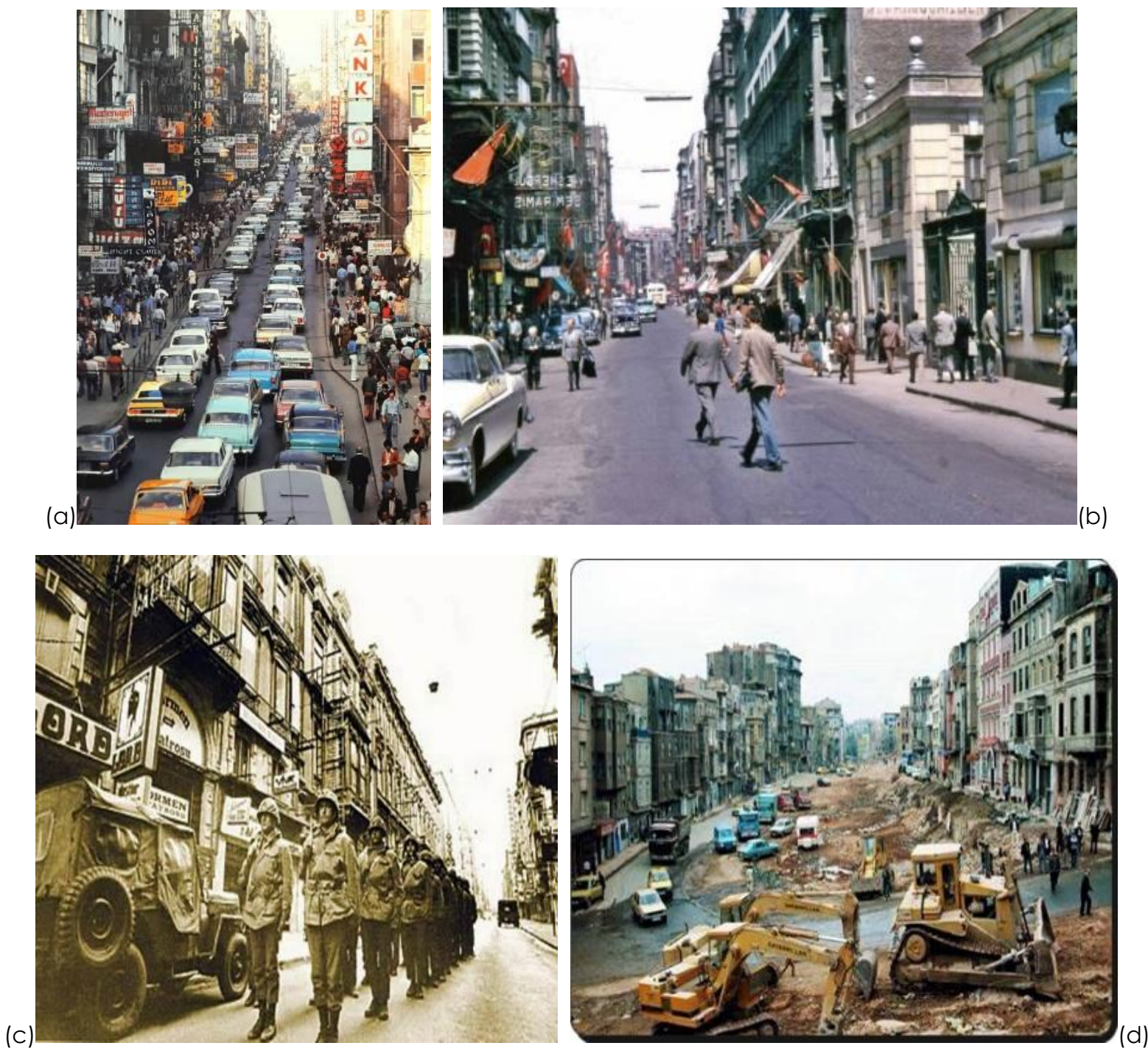

Figure 4 -(a) Istiklal Street in the 1970s(left above) (Twitter, 2020); (b) Istiklal Street in the early 1980s (right above) (Listelist, 2017);

(c) Istiklal Street in the time of 1980 Turkish Coup d'État (left below) (Listelist, 2014); (d) the construction works of Tarlabası Boulevard parallel to Istiklal Street in 1986 (right below) (Jaddeyekabir, 2012).

\section{The 1990s: Globalisation and Neoliberal Challenges and Modification with highly controversial projects}

After opening Tarlabaşı Boulevard, Istiklal Street has subsequently been pedestrianised in 1990 (see Figure $5 ; 1^{\text {st }}$ photo) to improve the attractiveness of the area for the business sector and tourists. After many attempts, in 1993, the area was declared an urban heritage zone (Ozus et al., 2012). The identity of Istiklal Street has changed significantly since this pedestrianisation. During the early pedestrianisation, many of the stores in the Street have suffered, only a small number of people came to spend time there. However, 
after the tram started running along the Street after the pedestrianisation (Paramita et al., 2014), the Street has been supported with the energy of festivals, art galleries and places of entertainment (see Figure 5; $2^{\text {nd }}$ photo). The Street's multicultural and multi-layered composition has resurfaced with the co-emergence of different actors (Tekin \& Akgün Gültekin, 2017).

In this process, conservative ideology has begun to rise after the local elections in 1994. The area's cosmopolitan identity has been approached with symbolic importance in terms of reviving the 'Ottoman model' (Bartu, 1999, p. 39) because Beyoglu was one of the most prominent public places and a sign mark of the cosmopolitan structure of diverse communities under the Ottoman rule. One of the first actions of the Beyoglu Municipality has been about the regulation of the tables and seats that sat on the pavements at Nevizade Street (a small parallel street to Istiklal Street full of bars, pubs, and taverns) to make the Street more accessible for the pedestrians (Güney, 2015).

Diverse urban transformation projects being implemented all over the neighbourhood of Beyoglu in the 1990s; within the process, local voices have not been considered, resistances have been suppressed (Say, 2016). Except for the discussions that have been put forward by social scientists, urban planners and architects, the huge amounts of discourses in social media showed that the multi-layered socio-cultural, and architectural structure of Istiklal Street has changed dramatically in a controversial way.
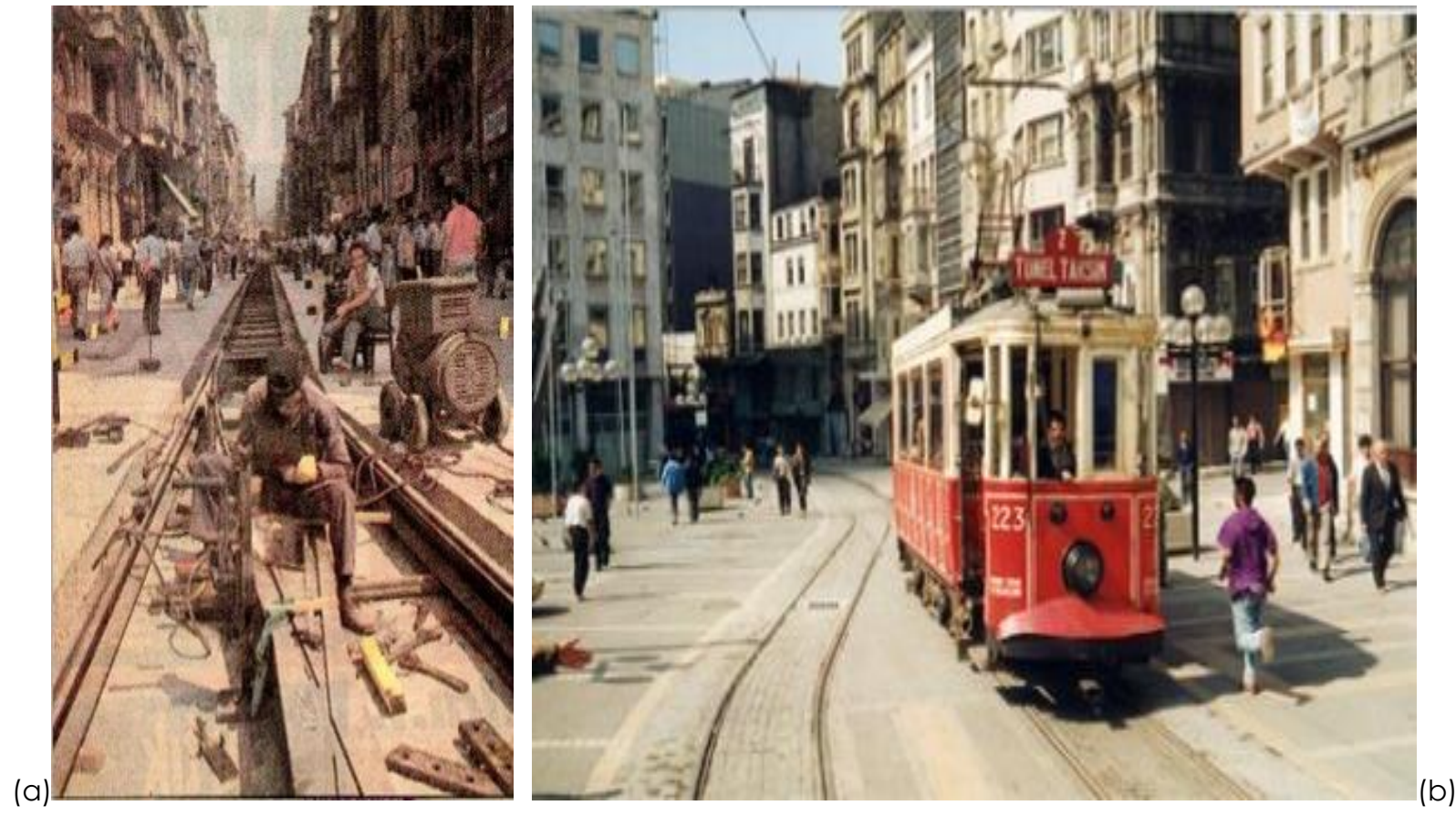

Figure 5 - (a) The pedestrianisation works of Istiklal Street in 1990 (left); (b) Istiklal Street in 1992 (right) (Wowturkey, 2006).

\section{From the 2000s: The capital-oriented urbanisation comes to fore}

Beyoglu Municipality has been one of the most important actors of the transformation of Istiklal Street after the 2000s (Güney, 2015), as the area has been "(...) full of ambiguity and variety, can host different social and economic relations, intertwines the formal and the informal, and is hard to contain and discipline", as it has required radical intervention. Besides the municipality-led urban renewal projects, the real estate investments of big local and foreign capital have had a considerable position in forming the transformation of Istiklal Street, so sales and purchases directed by investors led to important changes speedily (Adanali, 2011a). Istiklal Street started to transform into a marketplace for national and international goods and services to serve high-income groups with large-scale projects and interventions after the 2000s (Tekin \& Akgün Gültekin, 2017). 
As lots of cultural activity places such as veteran cinemas on Istiklal Street have been closed (Güney, 2015), some concert halls, small theatres have transformed into more profitable ventures such as hotels and shopping malls, the signposts of the place's cultural exuberance have disappeared, the area has lost its 'intellectual centre' of the city. However, with the rapid actions of real estate investments made by local and foreign capital, some new art centres have been opened on the Street by sponsored major banks and corporations, as well as prestigious stores owned by big brands. This situation may support the idea that Istiklal Street has been shaped by the role of capital within a process which urban transformations and cultural policies have been intertwined (Adanali, 2011a).

Many bookstores like Cumhuriyet, İstavrit, Adam, Can Bookstore, which have served before the 2000s, have closed. As a garment sector chain firm MANGO, although it has already had a store on the Street, purchased a building that included Istanbul Bookstore. Robinson Crusoe 389 Bookstore used to be one of the oldest bookstores and one of the Street's most attractive places in terms of both interior and exterior design, but it could not resist raising rents. Many bookstores have abandoned the Street to go back to Cağaloğlu, where much of the publishing industry in Istanbul located (Güney, 2015; Tekin \& Akgün Gültekin, 2017).

The sectors driving integration with global networks have raised in terms of space usage such as hotels, apart-hotels. The presence of hotels on and around Istiklal Street has jumped after 2005, the catering and entertainment facilities have turned into hotels and motels as hotel management is more profitable. Several international real estate firms and foreign funds have bought some buildings (Taş, 2010; Adanali, 2011b) such as Şark Aynalı Passage, and Nil Passage, but after the investors bought the buildings -which once had various facilities-, the buildings have lost chiefly their public usage. Also, most boutique hotels have been converted into hotels by big enterprises; for example, the Rumeli Han has been restored and merged with the building groups situated in the same parcel for a hotel project. There have been also attempts to transform some theatres into hotels, such as İkincikat Theater House and Beyoglu Terminal Theater examples. These changes have related to the development plan drawn up for Istanbul in 2009; the Istanbul Plan gave investors more initiative to determine the function of a building. The plan aimed to 'create gentrified, cleaned out, and upgraded built environments to be attractive for tourists and moneyed classes'; in this direction, the area has been adjusted for a new class of users and dwellers. Istiklal Street's user profile and entertainment sense have changed because of the efforts to turn it into a primarily tourism-oriented street (Tekin \& Akgün Gültekin, 2017). A new tourist profile of people coming from Gulf countries has increased in the area, parallel to the new styles' cafes and shops such as narghile cafes have been proliferated since many Syrian refugees lived in the city.

Istanbul has been the 2010 European Capital of Culture (Adanali, 2011a), this influenced both the physical and cultural modification of the environment (Keyder, 2010). After this occasion, Istanbul Shopping Fest (ISF) organised in Spring 2011 by a partnership between public and private enterprises and supported by shopping malls and big brands to 'modify Istanbul's high streets into the shopping, culture and entertainment centre of the world', the fest went on for 40 days. The transfer of public energies and resources to events such as Istanbul Shopping Fest resulted in problematic urban developments in the area, such as Demirören Shopping Mall (Güney, 2015).

In the summer of 2011, the Municipality removed the tables outside of the cafes in the area. People, especially the students, have started to go to other quarters like Beşiktaş, Karaköy and Kadıköy because of declining outdoor places (Tekin \& Akgün Gültekin, 2017). On the backstreets of Istiklal Street, such as Asmalımescid, setting up tables has been more difficult for restaurants, and cafes due to new regulations, so the loss of the outdoor facilities has sent people elsewhere where they can smoke, drink and eat with more joy.

As one of the major symbols of globalisation in the district, Demirören Shopping Mall has been opened in 2011 (Güney, 2015) after its original 1930s style structure has been demolished. Its facade rebuilt 10 meters taller than the original height of the former Deveaux Apartments, and the new interior design of the 
building has got some spatial problems (Tekin \& Akgün Gültekin, 2017). Therefore, the new form of the building has received criticism coming from diverse segments of the society (Adanali, 2011a). The opening of this shopping centre has proved that the socio-economical targeting profile of visitors has been turned into high-income groups; subsequently, the number of people visiting the Street has been influenced, and the visitors' profiles have changed, and unfortunately, the area converted into a place where serves no enough space for students, people with lower incomes, or activists. This newly structured shopping centre caused to quicken the penetration and elimination of places that characterised Istiklal Street.

Beyoglu Municipality's demands to make Istiklal Street a consumption cluster have led to the converting the small businesses into national or international chain stores (Güney, 2015). Small-scale cafes have come on the edge of shutting down their businesses; also, some special cafes and bars which have attracted people in different income groups have been moving to other areas of Istanbul. In the example of the patisserie İnci which has been served since 1944, it had moved in 2012. Ağa Restaurant, another veteran restaurant in the area, has closed its doors after years of struggle (Adanali, 2011a). Simultaneously, the chain stores of food sector such as Güllüoğlu, Mado and Kahve Dünyası have opened at least one shop on the Street (Tekin \& Akgün Gültekin, 2017).

The construction of Demirören Shopping Mall has immediately been pursued by changes in this area, the historical Cercle D'Orient building (next to Demirören Shopping Mall) containing Emek Movie Theatre, has been converted into another concentrated shopping area under the name of Grand Pera (Tekin \& Akgün Gültekin, 2017; Say, 2016). Some veteran stores at the Cercle d'Orient building entrance have been closed with the conception of creating a new 'culture-arts-entertainment gastronomy and fashion centre' in the area (Say, 2016). Other small theatres nearby have already closed their door; Emek, a veteran movie theatre on Istiklal Street, got marked for closing in April 2013. Then some protesters gathered for a sit-in. The protesters chanted the slogan, "Emek is Ours, Istanbul is Ours" by highlighting the importance of Emek in terms of the city's memory (Cusack, 2018), but the local voices have not been considered enough. In 2013, the Emek movie theatre was pulled down to reconstruct; it has been an emblematic example of the area's transformation process (Özlü, 2016).

In 2013, as part of the urban renewal of the region, the reconstruction idea of the 19th-century barracks in the Gezi Park area had been announced. At that time, 'Gezi Events' have been preceded by smaller-scale reactions against the Demirören Shopping Mall's construction (the demolition or re-functioning of the buildings such as the Emek Theater and Narmanlı Khan). Then, a civilian resistance happened in the Gezi Park in the summer of 2013, intending to object the reconstruction decision of the Topçu Barracks, and Istiklal Street has turned into a fighting scene concerning its spatial transformation (Tekin \& Akgün Gültekin, 2017). Then, Gezi protest has spread across the country (Cusack, 2018). In 2014, the iconic Taksim Square began to transform into a pedestrian area of 100,000 square meters, with the entire area paved by concrete. Although the area has been needed more green space, fresh flowers and trees (Xinhua, 2020).

After the Gezi protest, a law has passed to allow the eviction of the tenants of over ten years in Beyoglu. Due to this tenancy agreement, the Street's rooted stores have left the area as they could not afford the rising rent. Kelebek Korse, which has been one of the remarkable shops of the Street, has closed because its tenancy agreement has been terminated (Tekin \& Akgün Gültekin, 2017). So, Istiklal Street has seen the world's second-highest rent increases after San Francisco's Union Street in 2014 (Kömürcüler, 2018).

Istanbul Metropolitan Municipality had launched the work of changing the street floor in December 2016 due to ageing infrastructure and broken or removed granite pavement of the area. Therefore, the water, sewer, gas, electricity, and communication network passing underneath the Street has been completely renovated. In November 2017, the renovation and infrastructure work of Istiklal Street has come to an end after a year it was launched, revamped Istiklal Street opened and received mixed reactions from the users of the place. In the 650-meter section between Taksim Square and Galatasaray High School, green plastic material has been laid on the ground beneath the tram rails to absorb the tram's vibration. However, the street floor colour choice and the new look of the street floor have got mixed reactions in social media, 
many users likening the pavement to synthetic football pitches; also, a few 'Green Mile' jokes have been made (Daily Sabah, 2019). "What I see is a granite-covered river flowing in the middle of a concrete valley, you can neither see a shade nor a tree nor a planter", Atkaya wrote in his daily column. Even the Street had beautiful trees in the early 2000s (see Figure 6; $1^{\text {st }}$ photo). In the view of another columnist Basturk, the problem lies in "the endless renewal appetite although the same stones have been on the streets of some world cities for a thousand years as a sign of respect and care" (Xinhua, 2020).

The Cushman \& Wakefield report has revealed that the passenger traffic on Istiklal Street declined on weekdays and weekends in 2017 compared to the previous years, amid ongoing renovation works on its historic tramline (Cushmanwakefield, 2018). Several rental transactions have been made on the Street in the same year (Kömürcüler, 2018). In 2017, a mosque construction began at the entrance of Istiklal Street, the area has already had a small and masjid at the backstreet of Istiklal Street, but it was small and incapable to serve people sufficiently. The Ataturk Cultural Center on the square has been demolished to rebuilt anew under the new decision (Cusack, 2018), the plans of the building have been presented to the public.

Briefly, in the 2000s, the motto of 'beautifying and modifying the area by glorifying its past' has caused the rapid accumulation of the actual urban renewal actions in the area. Several historic buildings have passed through a change of both identity and function under the urban transformation and renovation projects. The specific businesses have had the risk of losing their buildings because of the obligations and regulations; also, they have been heavily affected by the distressed environment set by multiple matters. We have witnessed the disappearance of music shops, second-hand dress shops, silversmiths, and antique shops inside the famous arcades of Istiklal Street (Güney, 2015), especially bookstores have perished, the publishing offices, which include periodical, book and newspaper printing houses, have started leaving the Street. Istiklal Street, once shined out with its spatial and user diversity, begun to serve as one big shop window for displaying consumer goods (Tekin \& Akgün Gültekin, 2017). The 2000s have been the period when Istiklal Street has been faded due to the neoliberal economic policies and global challenges and capital-oriented urbanisation, so all the procedures damaged the distinctive composition of the area.

(a)
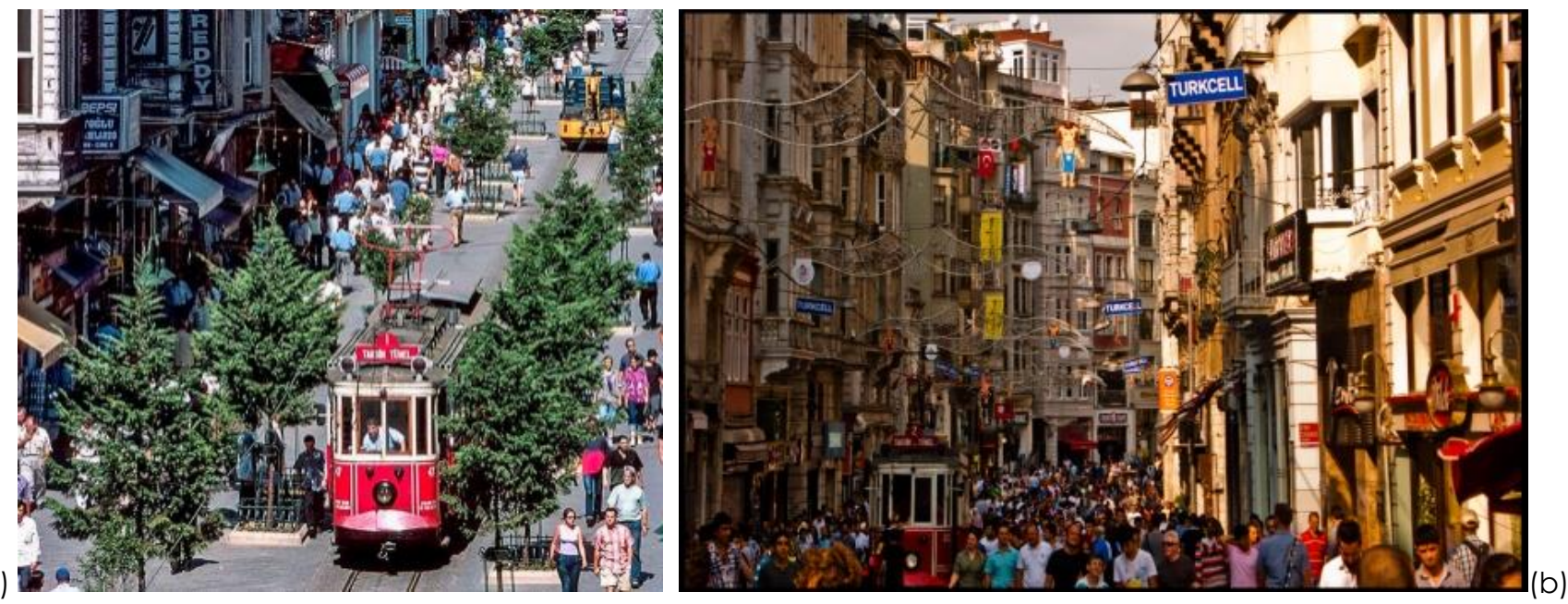

Figure 6 - (a) Istiklal Street in 2000 (left) (Onedio, 2017); (b) Istiklal Street in 2015 (right) (Travelstart, 2015).

\section{Conclusions}

In Turkey, which immediately affiliated to world capitalism after 1980, the pioneer of globalisation is Istanbul (Cavusoglu, 2010), and an attitude parallel to the global tendencies and liberal policies resulted in socio-cultural, economic, and spatial modifications of Istanbul (Keyder, 2009b; Keyder, 1999). From the 1990s until now, the urban modifications influenced both the urban texture and structure of Istiklal Street. Istiklal Street has staged remarkable changes in spatial organisations and zonal differentiation; the diversity in spatial use has declined; due to the rapid construction, renovation, and restoration projects in almost 
every section of Istiklal Street has transformed. With new urban policies, small scale trades and local brands began to disappear gradually, particularly the tiny shops of the Street have faced serious challenges; the number of stores of major brands has increased on the Street, and the rents have raised accordingly while the Street has been transforming (Güney, 2015). The spirit of this Street has been penetrated by the Street's long-standing symbolic enterprises closing one by one. Once a cosmopolitan place of old cinemas, bookshops, outdoor cafes, and dive bars, the Street has evolved into a tacky urban space dominated by chain stores and shopping malls (Arango, 2016). Istiklal Street's user profile has changed while the authentic tangible character and intangible atmosphere of the Street began to disappear. Some social exclusion has been carried due to the projects on the area. The restrictions concerning street musicians, activists, and performer actors have influenced the colourful, and perhaps some minor unruly components of Istiklal Street. So, Istiklal Street has standardised through looking like any main street located in anywhere of the world (Adanali, 2011a) and lost its diversity, distinctiveness and sensory uniqueness in Istanbul.

By the way, we witnessed that the Beyoglu Municipality initiated some projects for raising the awareness of the distinctive characteristics of the area -as they claimed. As one of the latest projects of the Municipality, 'Beyoglu Memory Project' generally linked with the collective memory issues of the area. This project aimed to establish a research centre concerning the historical, socio-cultural, and architectural values of the Beyoglu neighbourhood and create a database about the area's socio-cultural, historical, and architectural heritage. The other project 'Smart City Beyoglu,' aimed to collect information on this area's architectural layout through a digital database. In the context of this project, nearly every building on Istiklal street would have had a data matrix code to help for safeguarding the physical conditions and spatial background of the area. These projects have proved us the demand that the unique spatial composition of the area needs to be promoted with its distinctive qualities. This article thinks this kind of studies, applications, and works that provoke and promote the tangible and intangible mosaic of the place would be helpful. However, we could say that these projects have not been productive and sustainable enough.

As the final words, we stress that the latest changes and modifications, especially after the 1990s to now, hurt the area's tangible and intangible dimensions and experiential features. Moreover, all of them have caused a controversial shift in the way of distinctive qualities of Istiklal Street (see Figure 7), but it is best to focus on the future, on defining the next century of the area. We need to look at the question of 'what can we do now?' closely as the first step. This study firstly suggests that it needs to be avoided to propose clear-cut urban solutions for the problems that Istiklal Street will face. Secondly, the historical, socio-spatial, and intangible texture of the Street need to be investigated in different perspectives before implementing the projects in the area. Thirdly, the planning and designing of the area need to include participants from all parts of the society, including professional groups such as urban designers, architects, sociologists, as well as civil activist groups, artists, and local people. We know the future of this multi-layered area is based on the potentials of urban probabilities, socio-spatial compositions, and intangible dimensions of everyday life on the Street; in the end, we hope 'Istiklal wins.' 


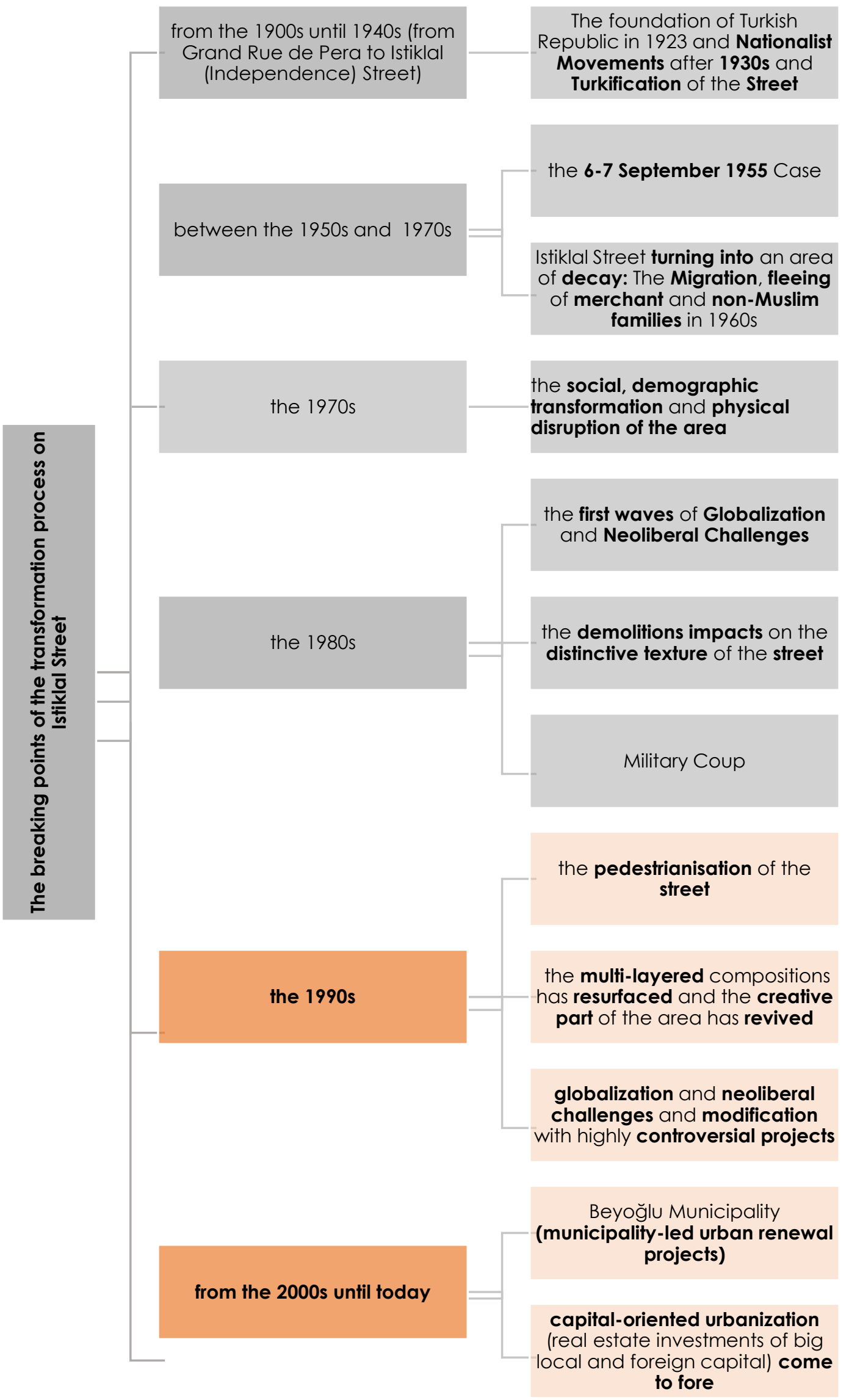

Figure 7 - The graphic shows the main spots on the transformation process of Istiklal Street. Source: Author. 


\section{Acknowledgements}

The author would like to thank Professor Jonathan Hale and Dr Didem Ekici from the University of Nottingham, who provided insight and expertise to the study.

\section{References}

Adanali, Y. (2011a). De-spatialised space as neo-liberal Utopia: Gentrified Istiklal Street and commercialised urban spaces. Red Thread Magazine. 3. Retrieved on 5 February 2019 at https://red-thread.org/en/de-spatialized-space-as-neoliberalutopia-gentrified-Istiklal-street-and-commercialized-urban-spaces/

Adanali, Y. (2011b). Klonlanmış Bir Anacadde: Istiklal. Mutlu Kent. Retrieved on 3 February 2019 at https://mutlukent.blog/2011/02/25/klonlanmis-bir-anacadde-Istiklal/amp/

Akin, N. (1994). Beyoglu, Dünden Bugüne Istanbul Ansiklopedisi. Istanbul: Kültür Vakfı ve Tarih Vakfı Ortak Yayını.

Akin, N. (2002). 19. Yüzyılın İkinci Yarısında Galata ve Pera. Istanbul: Literatür.

Akpınar, I. (2014). Remapping Istanbul: Taksim after Gezi. In Erkut, G. \& Shirazi, M. R. (Eds.). Dimensions of urban redevelopment, the case of Beyoglu (p. 31-39). Istanbul, Berlin: TU Berlin.

Arango, T. (2016). On Istiklal, Istanbul's Champs-Élysées, Symbols of a City's Malaise. Retrieved on 19 February 2019 at https://www.nytimes.com/2016/09/21/world/europe/Istiklal-istanbul-turkey.html

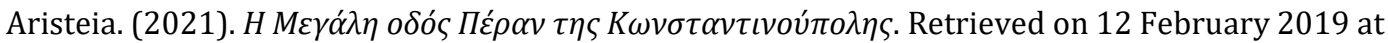
https://aristeia.site/archives/24136

Ash, J. (1997). Istanbul's Glitter Domes. Retrieved on 8 February 2019 at https://www.nytimes.com/1997/05/11/tmagazine/istanbuls-glitter-domes.html

Bartu, A. (1999). Who Owns the Old Quarters? Rewriting Histories in a Global Era. In Keyder, Ç. (Ed.). Istanbul Between the Global and the Local (p. 31-45). Lanham: Rowman and Littlefield.

Batur, A. (2007). Galata and Pera 1 A Short History, Urban Development Architecture and Today. ARI: The Bulletin of the Istanbul Technical University. 55(1), 1-10. Retrieved on 6 February 2019 at http://www.levantineheritage.com/pdf/Galata-Pera-Afife-Batur.pdf

Bellek.beyoglu.bel. (2012). Zaman Tünelinde Beyoğlu/Kent Müzesi'ne Doğru, 6. Daire-i Belediye'den Beyoğlu Belediyesi’ne 155 Yll. Retrieved on 7 September 2019 at http://bellek.beyoglu.bel.tr/download/Zaman_Tunelinde_Beyoglu_2012.pdf

Boratav, K. (2008). Türkiye Íktisat Tarihi 1908-2007. Ankara: İmge Kitabevi.

Can, A. (2012). A Comparison on two Cities and their two Main Streets: Istiklal Caddesi and Kärtner Strasse. Online Journal of Marmara University, 10(37), 139-150. http:// dx.doi.org/10.14783/od.v10i37.1012000194

Cavusoglu, E. (2010). İstanbul'da Planlama: Mekanın Yeniden Üretimi ve Sınıfsal Sonuçlar. In Keyder, Ç. (Der.). Küreselleșen İstanbul'da Ekonomi (p. 36-52). Istanbul: Osmanlı Bankası Arşiv ve Araştırma Merkezi Yayınları.

Cezar, M. (1991). XIX. Yüzyıl Beyoğlusu. İstanbul: Akbank Ak Yayınları.

Cusack, B. (2018). Urban Policy Shapes The 'New Turkey'. Retrieved on 4 February 2019 at https://www.forbes.com/sites/brennancusack/2018/06/30/urban-policy-shapes-the-new-turkey/\#6364a01374ca

Cushmanwakefield. (2018). Istanbul High Streets. Retrieved on 5 September 2019 at https://www.cushmanwakefield.com/en/turkey/insights/istanbul-ana-alisveris-caddeleri

Daily Sabah. (2019). Revamped Istiklal Street Partially Opens, Receives Mixed Reactions. Retrieved on 4 February 2019 at https://www.dailysabah.com/istanbul/2017/11/16/revamped-Istiklal-street-partially-opens-receives-mixed-reactions

Dökmeci, V. (1990). Tarihsel gelişim sürecinde Beyoğlu. Istanbul: Turing.

Dokmeci, V., \& Ciraci, H. (1988). Pera: A threatened historic European city within Istanbul. Ekistics, 333, November December, 359-369.

Eder, M., \& Öz, Ö. (2014). Neoliberalization of Istanbul's Nightlife: Beer or Champagne? International Journal of Urban and Regional Research. 39, 284-304. https://doi.org/10.1111/1468-2427.12156 
Ekmekci, O. (2012). Neoliberal Urbanisation in the case of Istanbul: Spatial Manifestations and Ways of Contesting It (Master Thesis). School of Architecture and the Built Environment (ABE), Royal Institute of Technology, Stockholm.

Ekmekci, O. (2014). Contesting neo-liberal urbanism in Istanbul: the case of Taksim Square and beyond. In Moksnes, H. \& Melin, M. (Eds). Claiming the City: Civil Society Mobilisation by the Urban Poor (p. 139-147). Uppsala: Uppsala University.

Enlil, Z. M. (1994). Continuity and change in Istanbul's nineteenth century neighbourhoods: From traditional house to apartment house (Ph.D. Thesis). University of Washington, Seattle, WA.

Ertep, H. (2009). Chaos or homogenisation? The role of shop signs in transforming urban fabric in Beyoglu, Istanbul. Visual Communication, 8(3), 263-272. https://doi.org/10.1177/1470357209106468

Eskiistanbul. (2019). Eski İstanbul Fotoğrafları Arşivi. Retrieved on 22 February 2019 at http://www.eskiistanbul.net/895/Istiklal-caddesi-1910

Faroqhi, S. (2008). Osmanlı Kültürü ve Gündelik Yaşam Ortaçağdan Yirminci Yüzyıla. Istanbul: Tarih Vakfı.

Güney, E. E. (2015). Big fish eats the small fish; Urban renewal in Istiklal Street and the closure of the small shops. In Architectural Design Conference 2015 On Current Designs and Design Methodologies Proceedings (p. 151-167). Istanbul, Turkey: Dakam.

Haberturk. (2013). 6-7 Eylül olayları. Retrieved on 15 February 2019 at

https://www.haberturk.com/haber/haber/987491-6-7-eylul-olaylari

Isik, B. I. (2010). Spatial Impacts of Globalization: Case Study Maslak İstanbul (Master Thesis). Middle East Technical University, Ankara, Turkey.

Jaddeyekabir. (2012). Tarlabaşı I. Retrieved on 14 February 2019 at https://jaddeyekabir.com/2012/07/29/tarlabasi-i/

Kayra, C. (1990). İstanbul, Zamanlar ve Mekanlar. İstanbul: Akyayınları.

Keyder, C. (1999). Istanbul: Between the global and the local. Lanham, MD: Rowman \& Littlefield.

Keyder, C. (2009a). Istanbul in a Global Context. Urban Age Istanbul Conference. London: London School of Economics and Political Science.

Keyder, C. (2009b). Arka Plan. In Guvenc, M. (Ed.). Eski İstanbullular, Yeni İstanbullular (p. 9-40). İstanbul: Ofset.

Keyder, Ç. (Ed.) (2010). Küreselleşen İstanbul'da Ekonomi. İstanbul: Osmanlı Bankası Arşiv ve Araştırma Merkezi Yayınları.

Kömürcüler. G. (2018). Istanbul's busiest avenue Istiklal hopes to bring back good old days. Retrieved on 18 June 2019 at https://www.hurriyetdailynews.com/istanbuls-busiest-avenue-iskital-hopes-to-bring-back-good-old-days-125393.

Köse, Y. (2011). Imparatorluk Başkentinden Megakente. İstanbul: Kitap.

Listelist. (2014). İstanbul'un Hiçbir Yerde Görmediğiniz 38 Kâbus Gibi Fotoğrafı. Retrieved on 12 February 2019 at https://listelist.com/eski-istanbul-fotograflari/

Listelist. (2017). Istiklal Caddesi'nin Geçmişten Günümüze Nasıl Değiștiğini Gösteren 15 Fotoğraf. Retrieved on 11 February 2019 at https://listelist.com/Istiklal-caddesi/

Öktem, B. (2011). İstanbul'da Neoliberal Kentleşme Modelinin SosyoMekansal İzdüşümleri. İÜ Siyasal Bilgiler Fakültesi Dergisi, 0(44), 25-30.

Öncü, A., \& Weyland, P. (Eds.). (1997). Space, Culture and Power: New Identities in Globalising Cities. New York: Zed Books.

Onedio. (2017). Yeni Halinde 'Tek Bir Ağaç Yok' Eleștirisi ve Çağrı: 'Istiklal Caddesi Yeniden Ağaçlandırılsın'. Retrieved on 19 February 2019 at https://onedio.com/haber/yeni-halinde-tek-bir-agac-yok-elestirisi-ve-cagri-Istiklal-caddesi-yenidenagaclandirilsin-769854

Özlü, N. (2016). Dönüşen Beyoglu Üzerine Notlar: Cercle d’Orient ve Emek Sineması Örneği. Mimarist, 3(57), 24-29.

Ozus, E., \& Dokmeci, V. (2005). Effects of Revitalisation in Historical City Center of Istanbul. Internatıonal Real Estate Review, 8(1), 144-159.

Ozus, E., Akin, D., \& Çiftçi, M. (2012). Hierarchical Cluster Analysis of Multicenter Development and Travel Patterns in Istanbul. Journal of Urban Planning and Development, 138(4), 303-318. https://doi.org/10.1061/(ASCE)UP.19435444.0000121 
Paramita, S., Reyes, C., Duarte, D., Rojas, H., \& Perez, A. (2014). Commuting dynamics in Istiklal Street. In Erkut, G. \& Shirazi, M. R. (Eds.). Dimensions of urban re-development, the case of Beyoglu (p. 197-223). Istanbul, Berlin: TU Berlin.

Pinterest. (2019). Istiklal caddesi - 1950 ler. Retrieved on 14 February 2019 at https://www.pinterest.se/pin/387380005421332331/

Placesbrands. (2015). Privilege and poverty: how Beyoglu shaped Istanbul's city brand. Retrieved on 15 February 2019 at http://placesbrands.com/privilege-and-poverty-how-beyoglu-shaped-istanbuls-city-brand

Sargut Gelen, S. (2019). Mekânsal Kimliğin Sürdürülmesinde Tarihî Kent Merkezlerinin Kamusal Gücünün Kentsel Tasarım Bağlamında Değerlendirilmesi: Istiklal Caddesi Aksı ve Taksim Meydanı (İstanbul) Örneği. Retrieved on 5 September 2019 at https://e-skop.com/skopbulten/tezler-mek\%C3\%A2nsal-kimligin-surdurulmesinde-tarih\%C3\%AE-kent-

merkezlerinin-kamusal-gucunun-kentsel-tasarim-baglaminda-degerlendirilmesi-Istiklal-caddesi-aksi-ve-taksim-meydaniistanbul-ornegi/5441.

Say, S. K. (2016). Serkldoryan-Emek Bloğundan Grand Pera'ya: Kazanılanlar-Kaybedilenler. Mimarist, 3(57), $30-41$.

Steemit. (2020). Photos of Istanbul in 1960-70s (Golden Days). Retrieved on 11 February 2019 at

https://steemit.com/history/@onurjones/photos-of-istanbul-in-1960-70s-golden-days

Taş, D. (2010). Beyoglu Street. Retrieved on 10 January 2019 at

http://www.sabah.com.tr/ekonomi/2010/12/03/beyoglu_street

Tekin, İ., \& Akgün Gültekin, A. (2017). Rebuilding of Beyoglu-Istiklal Street: A comparative analysis of urban transformation through sections along the Street 2004-2014. METU Journal of the Faculty of Architecture, 34(2), 153-179.

https://doi.org/10.4305/metu.jfa.2017.2.12

Travelstart. (2015). Istanbul: Taking the City by Storm. Retrieved on 16 February 2019 at http://www.travelstart.com.eg/blog/guide-to-istanbul/

Turan, N. (2011). Towards an Ecological Urbanism for Istanbul. In Sorensen, A., \& Okata, J. (Eds.). Megacities: Urban Form, Governance, and Sustainability (p. 223-244). London: Springer.

Twitter. (2020). Unutulmaz Fotoğraflar. Retrieved on 18 February 2019 at https://twitter.com/unutulmazfoto/status/1241005038782296064?lang=tr

Unlu Yucesoy, E., \& Guvenc, M. (2010). Istanbul'un Yeni Zamanları; 1990 Sonrası İktisadi Ve Sosyal Yapıda Değişme. In Keyder, C. (Ed.). Küreselleşen İstanbul'da Ekonomi (p. 12-19). Istanbul: Osmanlı Bankası Arşiv ve Araştırma Merkezi Yayınları.

Üstdiken, B. (1994). Istiklal Caddesi. In Tekeli et al., (Eds.) Dünden Bugüne Istanbul Ansiklopedisi (p. 265-271). Istanbul: Ministry of Culture.

Wowturkey. (2006). İstanbul Taksim-Tünel Nostaljik Tramvay Hattı (T2). Retrieved on 21 February 2019 at http://wowturkey.com/forum/viewtopic.php?t=3153\&start=20

Wowturkey. (2015). Istanbul IETT Otobüsleri - Tarihçe, Nostalji ve Hatıralar (IETT Buses, History and Nostalgia). Retrieved on 13 February 2019 at http://wowturkey.com/forum/viewtopic.php?p=4517492

Xinhua. (2020). Facelift of Istanbul's Famous Avenue Draws Fire - Xinhua. English.News.Cn. Retrieved on 1 September 2019 at http://www.xinhuanet.com/english/2017-05/13/c_136278072.htm.

Yada Akpinar, İ. (2010). Istanbul'da Modern Bir Pay-i Taht: Prost Planı Çerçevesinde Menderes'in İcraatı. In Bilsel, F. C., \& Pinon, P, Imparatorluk Başkentinden Cumhuriyet'in Modern Kentine: Henri Prost'un İstanbul Planlaması (1936-1951) (p. 167199). Istanbul: Istanbul Araştırmaları Enstitüsü.

Yalçintan, M. C., Çalişkan, Ç. O., Çilgin, K., \& Dündar, U. (2014). İstanbul Dönüşüm Coğrafyası. In Candan, A. B., \& Özbay, C. (Eds.). Yeni İstanbul Çalışmaları: Sınırlar, Mücadeleler, Açılımlar (p. 47-70). İstanbul: Metis Yayınları.

Editor: Fábio Duarte

Received: Nov. 16, 2019

Approved: Dec. 20, 2020 